\title{
Intertidal rivulets and creekbanks: corridors between tidal creeks and marshes
}

\author{
Lawrence P. Rozas*, Carole C. McIvor**, William E. Odum \\ Department of Environmental Sciences, Clark Hall, University of Virginia, Charlottesville, Virginia 22903, USA
}

\begin{abstract}
We sampled rivulets and creekbanks of tidal freshwater creeks (Virginia, USA) with flume nets between June and October 1986 to determine whether fishes preferentially use rivulets to reach the marsh surface. The average number of fishes collected in rivulets was more than 3 times that taken on creekbanks. Average total fish biomass was more than 14 times greater in rivulets. We estimated that rivulets occupied only $3 \%$ of the area along our study creeks. Therefore, despite a preference for rivulets as corridors, most fishes $(88 \%)$ reach the marsh surface via creekbanks. Depositional creekbanks are the primary corridors between tidal creeks and the marsh surface.
\end{abstract}

\section{INTRODUCTION}

During the rising tide, fishes regularly move from tidal creeks onto the vegetated marsh surface (Miller \& Guillory 1980, Talbot \& Able 1984, Zimmerman \& Minello 1984, Targett 1985, McIvor \& Odum 1986 Rozas \& Odum 1987a). The most extensive corridor to the marsh surface is the homogeneous, undissected marsh-creek interface, henceforth called creekbanks.

Fishes preferentially reach the marsh surface from sites within permanent creek channels that have shallow gently sloping profiles, i.e. depositional banks, (McIvor \& Odum 1988) and from localities that have abundant submerged aquatic vegetation (Rozas \& Odum 1987b). By estimating predation encounter rates of tethered prey fishes, Rozas (1987) and McIvor \& Odum (1988) demonstrated experimentally that such subtidal sites offer greater protection from piscivorous predators than comparable areas which differ in having greater depth (i.e. erosional banks) or reduced cover. Their studies suggest that quickly reaching the densely vegetated marsh surface on the rising tide is important to fishes of a size vulnerable to the predators in permanent creek channels.

Another corridor to the marsh surface is provided by rivulets, small intertidal creeks or channels that drain

Present addresses:

- US Army Engineer, Waterways Experiment Station, Box 631, CEWES-ER-W, Vicksburg, Mississippi 39180, USA

- Ecosystems Center, Marine Biological Laboratory, Woods Hole, Massachusetts 02543, USA the marsh surface. Though only tens of centimeters lower than the general marsh surface, rivulets begin to flood earlier on the rising tide and remain inundated longer than the remainder of the marsh surface, including creekbanks.

Our objectives were to (1) test the hypothesis that fishes preferentially use rivulets compared to the adjacent undissected creekbanks to reach the marsh surface, and (2) estimate the relative importance of creekbanks and rivulets as corridors between tidal creeks and the marsh surface.

\section{STUDY AREA}

We sampled fishes at Parsons Island Marsh $\left(37^{\circ} 21^{\prime} \mathrm{N}, 76^{\circ} 53^{\prime} \mathrm{W}\right)$, a tidal freshwater marsh system located ca $18 \mathrm{~km}$ west of Williamsburg, Virginia, USA (Rozas \& Odum 1987a). The mean amplitude of spring tides was $0.70 \mathrm{~m}$ (US Department of Commerce 1985). Water temperature averaged $27^{\circ} \mathrm{C}$ (range $=20$ to $32^{\circ} \mathrm{C}$ ) and mean salinity was $2.4 \%$ (range $=0.6$ to $4.0 \%$ ).

\section{MATERIALS AND METHODS}

We used flume nets (McIvor \& Odum 1986) to sample fishes swimming onto the marsh surface via both depositional creekbanks and intertidal rivulets from the headwater creeks studied by Rozas \& Odum (1987a). Unless otherwise stated, flume design and 
sampling procedures were identical to Rozas \& Odum (1987a). Briefly, the flume net consisted of parallel walls ( $20 \mathrm{~m}$ long) of $6 \mathrm{~mm}$ mesh netting enclosed at the back, extending from the creek bank into the high marsh, and oriented perpendicular to the creek axis. A conical end net placed at the $1.5 \mathrm{~m}$ wide flume mouth at slack high water captured fishes as the tide ebbed.

In each of 3 creek drainages we placed 2 flumes, one on a depositional creekbank and one on an intertidal rivulet nearby. Rivulet flumes differed from creekbank flumes in 2 ways. Whereas creekbank flumes enclosed long rectangular areas of marsh, rivulet flumes followed the contours of and enclosed meandering rivulets. Therefore, rivulet flumes encompassed halfmoon or 'S-shaped' intertidal areas. Secondly, the mesh size of end nets on rivulet flumes was $6 \mathrm{~mm}$, that on creekbank flumes was $3 \mathrm{~mm}$. The differences in mesh size constituted a conservative test of our first hypothesis. Both creekbank and rivulet flumes sampled fishes entering a $1.5 \mathrm{~m}$ wide swath of intertidal habitat. We collected fishes monthly at the 3 creekbank and 3 rivulet flumes on daytime spring tides in June, July, September and October 1986, for a total of 24 samples.

Using unbaited minnow traps, we collected mummichog Fundulus heteroclitus, and banded killifish $F$. diaphanus in tidal creeks at low tide and in rivulets on both flood and ebb tides in June, July and September 1986. To minimize trap effects on stomach contents, we removed fishes every $5 \mathrm{~min}$. After preservation in $10 \%$ formalin, we estimated stomach fullness with the method of Frost (1943).

Statistical analyses. We used a split plot design in which creek drainage was the unit of replication. For this reason and because flumes were sampled over time, we used a multivariate approach to repeated measures analysis of variance to test for differences in catch (number) and biomass ( $g$ preserved wet weight) between creekbank and rivulet flumes (Winer 1971 , Hull \& Nie 1981, O'Brien \& Kaiser 1985). The data were square-root transformed prior to analyses (Sokal \& Rohlf 1981). We did not conduct statistical tests for individual species because we had no a priori hypotheses relating to species-specific differences in microhabitat selection.

\section{RESULTS AND DISCUSSION}

We collected 19 fish species in 12 families (2551 individuals) weighing $10.142 \mathrm{~kg}$ (Table 1). Mummichog, banded killifish, pumpkinseed Lepomis gibbosus, mosquitofish Gambusia affinis, bay anchovy Anchoa mitchilli, spottail shiner Notropis hudsonius, bluegill Lepomis macrochirus, and bluespotted sunfish
Enneacanthus gloriosus accounted for $94.1 \%$ of the total catch. When a single specimen of common carp Cyprinus carpio was excluded, these 8 species also contributed $90.3 \%$ of the total biomass.

Fish catch was significantly greater in rivulet flumes $\left(F_{1,2}=21.123, p \leq 0.044\right)$, averaging more than 3 times that collected from creekbank sites (Fig, 1). Of the 8 most abundant species only bay anchovy were more abundant at creekbank sites. Total fish biomass was significantly greater at rivulet flumes as well $\left(\begin{array}{ll}F_{1} & 2\end{array}\right.$ $=22.274, p \leq 0.042$ ), averaging more than 14 times greater in rivulets (Fig. 2). Again, bay anchovy was the only dominant species which differed from this general pattern (Fig. 2).

Our study extends previous work on the importance of intertidal marsh habitats for fishes by demonstrating the use of rivulets as preferred points of access to freshwater marshes. When using rivulets, fishes maximize the amount of time spent in shallow intertidal as opposed to subtidal habitat, a behavior which has 2 possible benefits for small fishes; reduction of the risk of predation from piscivorous fishes, and access to an expanded foraging area (Mclvor et al. 1988). Although predation pressure in intertidal habitats has not been compared directly with that in permanent creeks, large predators are rare in samples from both intertidal creeks (Shenker \& Dean 1979, Reis \& Dean 1981, Rozas \& Hackney 1984) and the marsh surface (Rozas \& Odum 1987b, McIvor et al. 1988). In our study, only 7 individuals ( 6 largemouth bass Micropterus salmoides, and 1 white perch Morone americana) were piscivorous and these specimens were small juveniles (Table 1). Piscivorous fishes are abundant in permanent creeks (McIvor \& Odum 1988), and small fishes without cover there are vulnerable to predators (Rozas 1987 , McIvor \& Odum 1988).

Intertidal habitats are used extensively for foraging by mummichogs and banded killifish, the 2 most abundant species in our study. Both species moved into rivulets with an average of $<10 \%$ of their stomach volume filled. When leaving the rivulets, mummichogs averaged $80 \%$ gut fullness; banded killifish averaged $60 \%$. Although information on banded killifish is unavailable, intertidal habitats may be essential for mummichogs. Weisburg \& Lotrich (1982) showed experimentally that mummichog denied access to the salt marsh surface grew at significantly reduced rates compared to controls. Other fish species forage over intertidal areas as well. The intertidal zone was a significant feeding area for juvenile silver perch Bairdiella chrysura in a South Carolina salt marsh (Kleypas \& Dean 1983). The importance of the marsh surface for foraging has been described in detail for 11 species of fishes by Harrington \& Harrington (1961)

Though comparative data from salt marshes are lack- 
Table 1. Fishes collected on tidal freshwater marshes from June through October 1986 with rivulet and marsh-surface flumes Total catch (number of individuals) and total biomass (g preserved wet weight) are given for each species. Relative abundance $(\mathrm{RA}=\%$ total number) and relative biomass ( $\mathrm{RB}=\%$ total biomass) are given only when at least $1 \%$

\begin{tabular}{|c|c|c|c|c|}
\hline Scientific and common name & Total catch & RA & Total biomass & RB \\
\hline $\begin{array}{l}\text { Fundulus heteroclitus (Linnaeus) } \\
\text { mummichog }\end{array}$ & 1557 & 61.0 & 1208.1 & 11.9 \\
\hline $\begin{array}{l}\text { Fundulus diaphanus (Lesueur) } \\
\text { banded killifish }\end{array}$ & 290 & 11.4 & 234.2 & 2.3 \\
\hline $\begin{array}{l}\text { Lepomis gibbosus (Linnaeus) } \\
\text { pumpkinseed }\end{array}$ & 160 & 6.3 & 2713.0 & 26.8 \\
\hline $\begin{array}{l}\text { Gambusia affinis (Baird \& Girard) } \\
\text { mosquitofish }\end{array}$ & 135 & 5.3 & 32.4 & - \\
\hline $\begin{array}{l}\text { Anchoa mitchilli (Valenciennes) } \\
\text { bay anchovy }\end{array}$ & 113 & 4.4 & 40.8 & - \\
\hline $\begin{array}{l}\text { Notropis hudsonius (Clinton) } \\
\text { spottail shiner }\end{array}$ & 64 & 2.5 & 87.4 & - \\
\hline $\begin{array}{l}\text { Lepomis macrochirus Rafinesque } \\
\text { bluegill }\end{array}$ & 41 & 1.6 & 1376.7 & 13.6 \\
\hline $\begin{array}{l}\text { Enneacanthus gloriosus (Holbrook) } \\
\text { bluespotted sunfish }\end{array}$ & 40 & 1.6 & 53.2 & - \\
\hline $\begin{array}{l}\text { Menidia beryllina (Cope) } \\
\text { inland silverside }\end{array}$ & 38 & 1.5 & 15.0 & - \\
\hline $\begin{array}{l}\text { Ictalurus nebulosus (Lesueur) } \\
\text { brown bullhead }\end{array}$ & 31 & 1.2 & 14.4 & - \\
\hline $\begin{array}{l}\text { Etheostoma olmstedi Storer } \\
\text { tessellated darter }\end{array}$ & 30 & 1.2 & 21.3 & - \\
\hline $\begin{array}{l}\text { Notemigonus crysoleucas (Mitchill) } \\
\text { golden shiner }\end{array}$ & 29 & 1.1 & 434.0 & 4.3 \\
\hline $\begin{array}{l}\text { Gobiosoma bosci (Lacepede) } \\
\text { naked goby }\end{array}$ & 12 & - & 3.9 & - \\
\hline $\begin{array}{l}\text { Micropterus salmoides (Lacepede) } \\
\text { largemouth bass }\end{array}$ & 6 & - & 106.3 & 1.1 \\
\hline $\begin{array}{l}\text { Cyprinus carpio Linnaeus } \\
\text { common carp }\end{array}$ & 1 & - & 3780.0 & 37.3 \\
\hline $\begin{array}{l}\text { Morone americana (Gmelin) } \\
\text { white perch }\end{array}$ & 1 & - & 17.4 & - \\
\hline $\begin{array}{l}\text { Cynoscion regalis (Bloch \& Schneider) } \\
\text { weakfish }\end{array}$ & 1 & - & 3.5 & - \\
\hline $\begin{array}{l}\text { Notropis bifrenatus (Cope) } \\
\text { bridle shiner }\end{array}$ & 1 & - & 0.3 & - \\
\hline $\begin{array}{l}\text { Alosa pseudoharengus (Wilson) } \\
\text { alewife }\end{array}$ & 1 & - & 0.1 & - \\
\hline Total & 2551 & & 10142.0 & \\
\hline
\end{tabular}

ing, rivulets are likely preferred routes to the marsh surface there as well. Brackish and salt marsh rivulets on both the Atlantic and Gulf coasts contain high densities of small fishes (Subrahmanyam \& Drake 1975 , Cain \& Dean 1976, Bozeman \& Dean 1980, Rozas \& Hackney 1984).

The number of fishes that reach the marsh surface via rivulets is limited by both the size and number of rivulets along tidal creeks. At our study site, rivulets $(n=20)$ averaged $1.3 \mathrm{~m} \pm 0.7 \mathrm{SD}$ in width and $30.8 \mathrm{~cm}$ $\pm 12.6 \mathrm{SD}$ deep at their mouths, tapering to a few centimeters wide a short distance into the marsh. Therefore, the area available to fishes within each rivulet before the marsh surface flooded was small. When the marsh flooded, fishes could spill on to the adjacent marsh surface, but creekbanks were also available as corridors to the marsh surface at this time.

Using aerial photographs and ground truthing, we found that rivulet entrances occupied ca $3 \%$ of the distance along our study creeks. We assumed that the remaining area (97\%) contained equal amounts of depositional and erosional creekbanks. From data collected in our study and that collected previously (Rozas 1987, McIvor \& Odum 1988), we calculated that despite a preference for rivulets as corridors (Fig. 1), most fishes $(59 \%)$ reach the marsh surface via depositional creekbanks (Table 2).

Rivulets may be relatively more important as corridors in highly dissected marshes. Based on the 


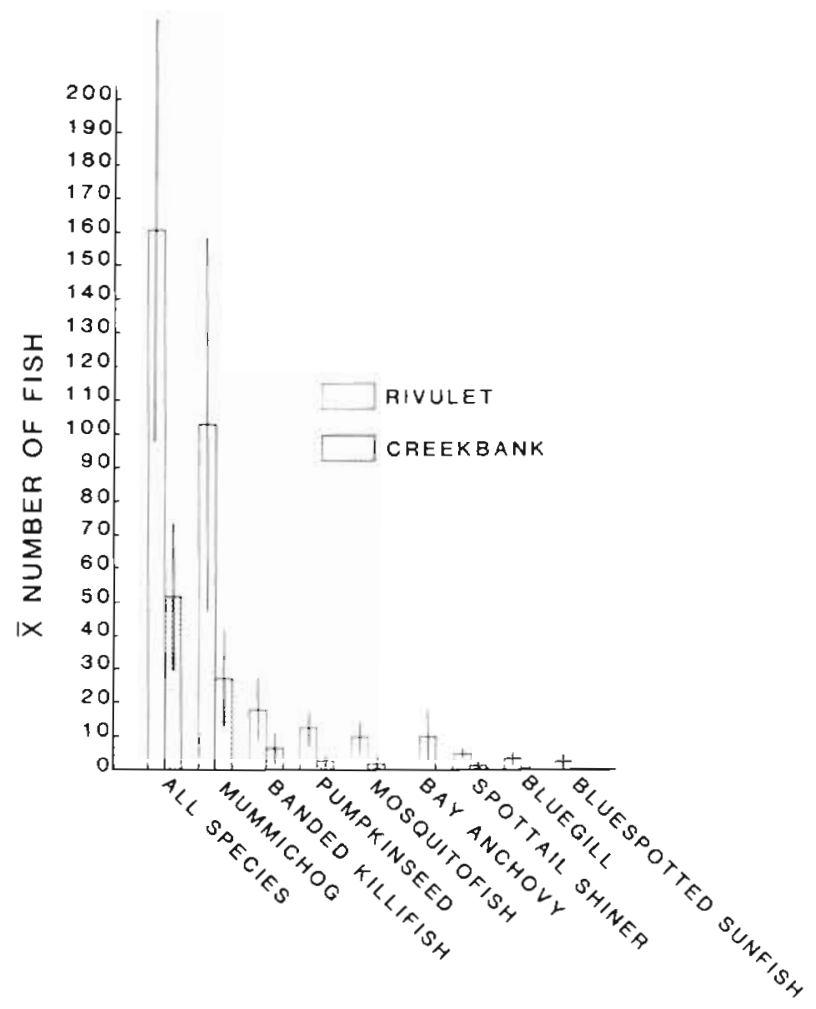

Fig. 1. Comparisons between rivulet and creekbank flumes of average total catch (all species combined) and average number of 8 numerically dominant species. Error bars represent 2 standard errors

data presented in Table 2, most fishes would reach the marsh surface via rivulets when rivulet entrances constituted at least $19 \%$ of the distance along a tidal creek. Although the average rivulet density along the tidal creeks in our study area was much less, the existence of such densities in other marshes is possible. Furthermore, the relative importance of rivulets as corridors may vary over time. If young marshes have better developed drainage systems than old marshes as Frey \& Basan (1978) have postulated, the relative impor-

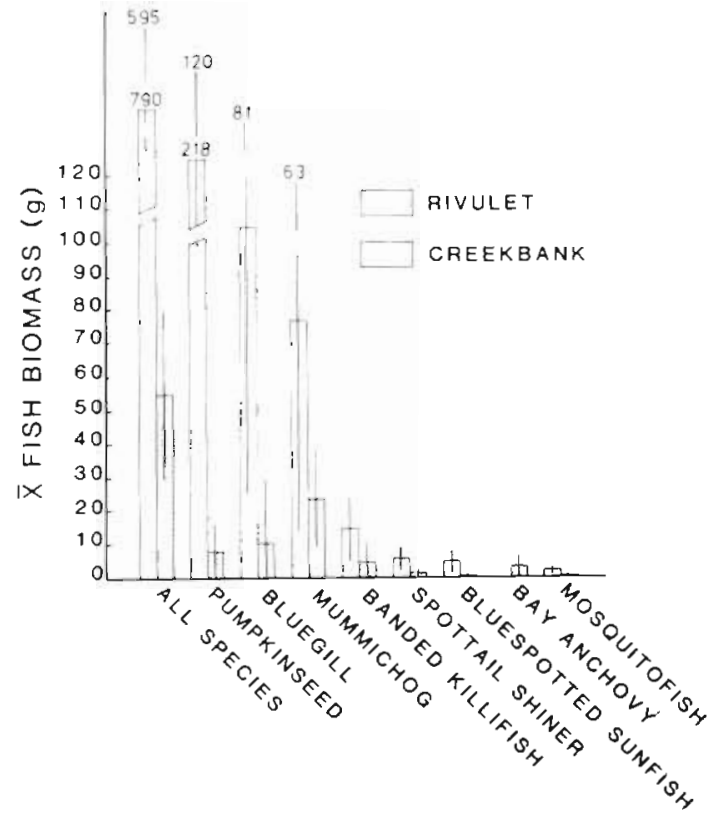

Fig. 2. Comparisons between rivulet and creekbank flumes of average total (all species combined) biomass ( $\mathrm{g}$ preserved wet weight) and average biomass of 8 numerically dominant species. Error bars represent 2 standard errors

tance of rivulets as corridors will be greatest in newly developed marshes and will decline as the marshes age.

Acknowledgements. Our study was supported in part by a Department Research Grant and Moore Award from the Department of Environmental Sciences, University of Virginia, and a grant (No. NA81AA-D-00025) to the Virginia Graduate Marine Science Consortium and the Virginia Sea Grant Program by the Office of Sea Grant, US Department of Commerce. We thank D. M. Gauthier, C. Walker, R. P. Rozas, C. M. Rozas, R. M. Chambers, J. P. Frye, K. J. Halama, and J. W. Harvey for field assistance. C. Bowman is acknowledged for granting us permission to work on his property. We gratefully acknowledge the hospitality and logistical support provided by David Brime of the Virginia Commission of Game and Inland Fisheries.

Table 2. Corridor width, average number of fish collected in each corridor (average catch), and total number fish and percentage of fish calculated to reach marsh surface via 3 possible corridors (rivulets, depositional creekbanks, and erosional creekbanks)

\begin{tabular}{lcccc|}
\hline Corridor & awidth $(\mathrm{m})$ & $\begin{array}{c}\text { Average catch } \\
\text { (Fish/1.5 m width) }\end{array}$ & Total fish & \% Total fish \\
\hline Rivulet & 6 & 160 & 640 & 12 \\
Depositional creekbank & 97 & 50 & 3233 & 59 \\
Erosional creekbank & 97 & $b_{25}$ & 29 \\
a Based on total tidal creek length of $100 \mathrm{~m} \times 2$ banks $=200 \mathrm{~m}$ (total corridor width) & \\
${ }^{\circ}$ Based on average fish catch from erosional creekbanks = half that from depositional creekbanks (McIvor \& Odum 1988)
\end{tabular}




\section{LITERATURE CITED}

Bozeman, E. L., Jr, Dean, J. M. (1980). The abundance of estuarine larval and juvenile fish in a South Carolina intertidal creek. Estuaries 3: 89-97

Cain, R. L., Dean, J. M. (1976). Annual occurrence, abundance and diversity of fish in a South Carolina intertidal creek Mar. Biol. 36: 369-379

Frey, R. W., Basan, P. B. (1978). Coastal salt marshes. In Davis, R. A., Jr (ed.) Coastal sedimentary environments. Springer-Verlag, New York, p. 101-169

Frost, W. E. (1943). The natural history of the minnow Phoxinus phoxinus. J. Anim. Ecol. 12: 139-162

Harrington, R. W., Harrington, E. S. (1961). Food selection among fishes invading a high subtropical salt marsh: from onset of flooding through the progress of a mosquito brood. Ecology 42: 646-666

Hull, C. H., Nie, N. H. (1981). SPSS update 7-9. McGraw-Hill, New York

Kleypas, J., Dean, J. M. (1983). Migration and feeding of the predatory fish, Bairdiella chrysura Lacepede, in an intertidal creek. J. exp. mar. Biol. Ecol. 72: 199-209

Mcivor, C. C., Odum, W. E. (1986). The flume net: a quantitative method for sampling fishes and macrocrustaceans on tidal marsh surfaces. Estuaries 9: 219-224

Mclvor, C. C., Odum, W. E. (1988). Food, predation risk and microhabitat selection in a marsh fish assemblage. Ecology (in press)

McIvor, C. C., Rozas, L. P., Odum, W. E. (1988). Use of the marsh surface by fishes in tidal freshwater wetlands. In: Sharitz, R. R., Gibbons, J. W. (eds.) Freshwater wetlands and wildlife. US Dept of Energy Symp. Ser. (CONF8603101) (in press)

Miller, C., Guillory, V. (1980). A comparison of marsh fish communities using the Wegener ring. Proc. Annu Conf. Southeast. Assoc. Fish and Wildl. Agencies 34: 223-233

O'Brien, R. G., Kaiser, M. K. (1985). MANOVA method for analyzing repeated measures designs: an extensive primer. Psychol. Bull. 97: 316-333

Reis, R. R., Dean, J. M. (1981). Temporal variation in the utilization of an intertidal creek by the bay anchovy (Anchoa mitchilli). Estuaries 4: 16-23
Rozas, L. P. (1987). Submerged plant beds and tidal freshwater marshes: nekton community structure and interactions. Ph. D. dissertation, University of Virginia, Charlottesville

Rozas, L. P., Hackney, C. T (1984). Use of oligohaline marshes by fishes and macrofaunal crustaceans in North Carolina. Estuaries 7: 213-224

Rozas, L. P., Odum, W. E. (1987a). Use of tidal freshwater marshes by fishes and macrofaunal crustaceans along a marsh stream-order gradient. Estuaries 10: 36-43

Rozas, L. P., Odum, W. E. (1987b). The role of submerged aquatic vegetation in influencing the abundance of nekton on contiguous tidal freshwater marshes. J. exp. mar. Biol. Ecol. 114: 289-300

Shenker, J. M., Dean, J. M. (1979). The utilization of an intertidal salt marsh creek by larval and juvenile fishes: abundance, diversity and temporal variation. Estuaries 2: $154-163$

Sokal, R. R., Rohlf, F. J. (1981). Biometry, 2nd edn. W. H. Freeman and Company, San Francisco, Califormia

Subrahmanyam, C. B., Drake, S. H. (1975). Studies on the animal communities in two north Florida salt marshes: Part I. Fish communities. Bull. mar. Sci. 25: 445-465

Talbot, C. W., Able, K. W. (1984). Composition and distribution of larval fishes in New Jersey high marshes. Estuaries 7: $434-443$

Targett, T. (1985). Utilization of salt marsh surface habitat by estuarine fishes (Abstract). Estuaries 8: 8A

U. S. Department of Commerce. (1984). Tide tables 1985 (high and low water predictions) east coast of North and South America, including Greenland. NOAA National Ocean Survey, Rockville, Maryland

Weisberg, S. B., Lotrich, V A. (1982). The importance of an infrequently flooded intertidal marsh surface as an energy source for the mummichog Fundulus heteroclitus: an experimental approach. Mar. Biol. 66: 307-310

Winer, B. J. (1971). Statistical principles in experimental design, 2nd edn. McGraw-Hill, New York

Zimmerman, R. J., Minello, T. J. (1984). Densities of Penaeus aztecus, $P$. setiferus, and other natant macrofauna in a Texas salt marsh. Estuaries 7: 421-433 